\title{
CONSUMER PREFERENCE OF PACKAGED RICE AND BULK RICE IN SURABAYA
}

\author{
Sri WIDAYANTI ${ }^{1}$ \\ Indra Tjahaja $\mathrm{AMIR}^{2}$ \\ Pawana Nur INDAH ${ }^{3 *}$ \\ Fanny SEPTYA ${ }^{4}$
}

Received: August 2019 | Revised: February 2020 | Accepted: April 2020

Please cite this paper as: Widayanti, S., et. al. (2020). Consumer Preference of packaged rice and bulk rice in Surabaya, Holistica Journal of Business and Public Administration, vol. 11, iss. 1, pp. 155-169

\begin{abstract}
This study aims to analyse consumer preference on the attributes of rice and describe the comparison of performance of packaged rice and bulk rice in the eyes of urban consumer. The method of this study uses survey on 100 respondents chosen purposively. The primary data that is obtained is analysed quantitatively using the attitude multi-attribute model from Fishbein. Based on the analysis result, it is known that expiration clarity is a positive attribute in both packaged rice and bulk rice, followed by the ease of obtaining in the bulk rice, and the contents in the packaged rice. The attributes with positive value indicates the key factor that determine consumer's assessment in choosing certain rice brand. From the semantic differential comparison, it is found that branded packaged rice is generally better in attributes compared to bulk rice. According to the results, the efforts to increase rice agro-industrial in local farmer level are recommended, so that they can enjoy the benefits of the multi-attributes attached in the branded packaged rice that they produced.
\end{abstract}

Keywords: Rice; Preference; Multi-attribute; Fishbein

\section{Introduction}

\footnotetext{
${ }^{1}$ Department of Agribusiness, Agriculture Faculty, Universitas Pembangunan Nasional "Veteran" East Java, Indonesia

2 Department of Agribusiness, Agriculture Faculty, Universitas Pembangunan Nasional "Veteran" East Java, Indonesia

${ }^{3}$ Department of Agribusiness, Agriculture Faculty, Universitas Pembangunan Nasional "Veteran" East Java, Indonesia, pawananurindahupnjatim@gmail.com

${ }^{4}$ Department of Agribusiness, Agriculture Faculty, Universitas Pembangunan Nasional "Veteran" East Java, Indonesia

* Corresponding author
} 
HOLISTICA Vol 11, Issue 1, 2020, pp. 155-169

Indonesia is a country produces and uses rice, so rice is the most strategic food commodity (Rohman et al., 2014). In the urban rice market, which is a destination for downstream rice, it is indicated that rice as a homogeneous food commodity has shifted to heterogeneous products (Abidin et. al, 2018). This shows that there is product differentiation in rice; in this case, it is the type and brand of rice. Product differentiation is one of the indicators in the identification of market structure (Ukav, 2017). The changes that occur on the indicators that form market structure is the result of the improvement of marketing functions (market behavior) which then form marketing performance in the form of increased marketing margin by marketing institutions that create added value through marketing functions that are carried out (Widayanti, 2018).

According to Septya (2018), the diversity of rice type and brand created by rice market actors, especially agro industry, changes the paradigm of the staple food commodity market from a perfectly competitive market to monopolistic market, where every behavior of marketing institutions in creating differentiation will improve marketing performance and expand market share. Differentiation is born based on consumer behavior as a factor of product demand (Dirisu, 2013). The development of consumer behavior in purchasing rice has changed in the last decade, where consumer starts to pay attention to product safety; package, brand, or size, which has not yet understood by local rice producers, but become a matter of competition for urban agro industry actors to dominate the rice markets.

Rice, as the staple food for most of the people in Indonesia has a large opportunity for its development, especially in the market development or trade. This opportunity can be realized, one of them by making rice products have better added value compared to other rice products in the market, both in terms of quality and quantity. One of the alternatives that can be done is by increasing the rice quality, starting from the selection of rice with the best quality until the final process, by providing branded package that not only aims to attract consumer's attention, but also increase the quality of the rice indirectly. The rice products in package which are now often found in the market is a product differentiation that have been exist before, since the consumer's taste in purchasing rice always changes in the packaging, brand, or size. The understanding of consumer behavior must be sought by rice producers in packaging so that the product can be sold in the market. Therefore, the manager or seller of this product must be able to identify consumer behavior, especially about the consumers' needs toward rice products.

As a metropolitan city with heterogeneous community and structural transformation that continue to develop, the availability of rice in Surabaya is dominated by rice from the East Java food storage area, namely Bojonegoro, Lamongan, Tuban, and Kediri Regency. Surabaya as the main target market of food storage area in East Java experiences the trend of preferences of urban community in deciding the type of rice consumption. The rice processing industry is growing rapidly, followed by the packaging industry to fulfil the reference of urban community, therefore in the market in Surabaya, the rice brand both from local brand and outside the city have been circulated. As a result, consumers will be faced with many choices, such as brand, packaging, or size, but the decision remains on 
HOLISTICA Vol 11, Issue 1, 2020, pp. 155-169

the consumers because it involves taste and purchasing power of the consumers. The phenomenon of rice brand diversity in Surabaya rice market indicates the attribute that inherent in the rice affects consumer behavior in liking certain rice type and brand. This study aims to analyse the consumer preference of rice attributes and describe the multiattribute performance of bulk rice and packaged rice in the eyes of consumers.

\section{Literature Review and Hypothesis}

\subsection{Consumer Preference}

Consumer preference is defined as a choice of like and dislike of someone towards a product or service consumed. According to Kotler (2008) in Ramdhani et al. (2012), consumer preference indicates consumer's favourite from a variety of product choices. Preference theory is used to analyse the level of satisfaction for consumers, for example, if someone wants to consume a product with limited resources, then he has to choose some alternatives, so that the value of utility or utility that is obtained is optimal. Consumer preference can be known by measuring the level of utility and relative importance of each attribute in a product. Physical attributes displayed on a product can cause the first attractiveness that can affect consumers. Assessment toward a product describes the consumer's attitude on the product, and at the same time reflects the consumer behaviour in spending and consuming a product.

\subsection{Fishbein Multi-Attribute Model}

The most popular attitude measurement used by consumer researchers is the Attitude Multi-Attribute Model from Fishbein. This model is called multi-attributes because it examines the consumer evaluation toward an object based on the evaluation on many attributes owned by the particular object. Another benefit from multi-attribute analysis is the implication of the development of new product. A multi-attribute model has been used and it is successful in predicting the market share of new product (Ramdhani, et al). Multi-attribute analysis also provides guidelines for the marketers to develop an appropriate attitude change strategy.

\subsection{Consumer Behaviour in Purchasing Decision}

Kotler (2008) in Ramdhani et al. (2012) stated that consumer behaviour can be defined as a process of decision making and individual activity physically that involves evaluation in using products or services. According to Engel, Blackward, and Miniard in Kumboro (2016), factors that affect consumer behaviour in making purchases are: (1) environmental influences; (2) individual influences and differences; (3) psychological process. The environmental influences include cultural, social class, personal, family, and situational factors. The individual differences include resources differences, namely economy, temporary, and cognitive resources. Psychological process includes motivation, perception, knowledge, and beliefs.

Based on the phenomenon in field associated to the theory, the following hypothesis is 
formulated:

- There is a key attribute that becomes the main consideration of consumer to choose certain rice type.

- Packaged rice is preferred by urban consumers rather than bulk rice due to the completeness of the attributes that attached to the packaged rice.

\section{Research Method}

\subsection{Determination of Research, Study Areas, and Respondents}

The type of this study is quantitative descriptive in the assessment of attitude, behavior, and preference of urban rice consumers on their choice toward rice type and brand. This study is done purposively to household respondents that consume bulk and packaged rice in Surabaya City. The data is obtained from primary data from informants during the research in field.

\subsection{Data Collection}

In determining the population of branded packaged rice consumers, it is conducted a preliminary survey to find out the total population. The population examined in this study is household consumers of bulk and packaged rice. The sampling technique used in this study is purposive sampling, amounted to 100 respondents. The population characteristic is the person who ever consume bulk rice and branded packaged rice. The primary data is obtained by distributing questionnaires and direct interview.

\subsection{Analysis Method}

The measurement of consumer preference in this study uses the attitude multi-attribute model from Fishbein. This model is called multi-attribute because it examines the consumer evaluation toward an object based on the evaluation on many attributes owned by the particular object. According to Engel, Blackwell, and Miniard (1995), Fishbein model describes that consumer behavior on a product or brand of a product is determined by two things, namely: (1) Trust toward the attribute owned by a product or brand (bi component), and (2) Evaluation of level of importance of a product or brand attributes. The Fishbein formulation is a multi-attribute model that can be formulated as follows:

$$
A o=\sum_{i=1}^{n} b i e i
$$

Information:

Ao: Attitude toward an object.

bi: Strength of trust that an object has ' $i$ ' attribute.

ei: Evaluation for' $i$ ' attribute, the number of this study is $=11$ 
$\mathrm{n}$ : Number of attribute that stands out, the number of this study is $=11$

\section{Results and Discussion \\ a. Rice Evaluation Analysis}

Evaluation analysis measures how important certain attributes of rice in the eyes of consumers. In this measurement, consumers are asked about their evaluation toward the attributes; is it important or unimportant. The results of the average evaluation are sorted from the largest to the smallest number (according to the scale criteria).

Table 1 Rice Evaluation Analysis

\begin{tabular}{clc}
\hline No. & Attribute & Ei \\
\hline 1 & Expiration clarity & 4,26 \\
2 & Ease of obtaining & 4,08 \\
3 & Content & 3,89 \\
4 & Condition & 3,78 \\
5 & Texture & 3,71 \\
6 & Price & 3,69 \\
7 & Taste & 3,67 \\
8 & Color & 3,66 \\
9 & Price & 3,64 \\
10 & Display & 3,39 \\
11 & Package size/portion & 3,31 \\
\hline
\end{tabular}

Source: Data Analysis Result, 2019

From the table above, it appears that expiration quality is the most important attribute for consumers in considering the type of rice. It also can be seen that consumers feel that the assessment (evaluation) of expiration clarity of rice is the main attribute to form the attitude towards the type of rice, followed by the evaluation on ease of obtaining, content, condition, texture, and et cetera.

\section{b. Belief Analysis of Bulk Rice}

Belief analysis in this study is the consumers' belief on an attribute, or how consumers assess certain attribute performance of bulk rice. After the attribute is determined, consumers will be asked about their belief to the certain attribute. The result of the belief analysis of bulk rice is written down below:

Table 2 Belief Analysis of Bulk Rice

\begin{tabular}{clc}
\hline No. & Attribute & bi \\
\hline 1 & Ease of obtaining & 3,89
\end{tabular}




\begin{tabular}{cll}
2 & Price & 3,86 \\
3 & Expiration clarity & 3,79 \\
4 & Content & 3,70 \\
5 & Taste & 3,59 \\
6 & Texture & 3,58 \\
7 & Condition & 3,57 \\
8 & Aroma & 3,54 \\
9 & Color & 3,54 \\
10 & Package size/portion & 3,40 \\
11 & Display & 3,37 \\
\hline
\end{tabular}

Source: Data Analysis Result, 2019

From the table above, it can be seen that the attribute of ease of obtaining has the best performance in consumers' perception. In other words, it can be stated that in forming the attitude toward the type of rice, consumers have belief that ease of obtaining bulk rice is the best attribute, compared to price, expiration clarity, content, taste, and et cetera. As for the display of bulk rice is the least preferred attribute by the consumers.

Associated with the previous evaluation analysis result, it seems that the expiration clarity which is considered the most important by consumers is in fact preferred by consumers, and this attribute is also ranked high in the consumers' perception. The attributes of package size/portion and display is also considered the smallest by consumers. This indicates that the attributes of package size/portion and display are considered unimportant and not preferred by consumers.

\section{c. Fishbein Multi-Attribute Attitude Analysis of Bulk Rice}

The attitude analysis of consumers (Ao) in each attribute on bulk rice in sequence from the largest value is shown in Table 3.

Table 3 Fishbein Multi-Attribute Attitude Analysis of Bulk Rice

\begin{tabular}{clccc}
\hline No. & \multicolumn{1}{c}{ Attribute } & Ei & Bi & $\begin{array}{c}\text { Ao } \\
\text { (ei.bi) }\end{array}$ \\
\hline 1 & Expiration clarity & 4,26 & 3,79 & 16,16 \\
2 & Ease of obtaining & 4,08 & 3,89 & 15,88 \\
3 & Content & 3,89 & 3,70 & 14,41 \\
4 & Price & 3,69 & 3,86 & 14,24 \\
5 & Condition & 3,78 & 3,57 & 13,50 \\
6 & Texture & 3,71 & 3,58 & 13,28 \\
7 & Taste & 3,67 & 3,59 & 13,15 \\
8 & Colors & 3,66 & 3,54 & 12,95 \\
9 & Aroma & 3,64 & 3,54 & 12,89 \\
10 & Display & 3,39 & 3,37 & 11,41 \\
11 & Package size/portion & 3,31 & 3,40 & 11,23 \\
\hline
\end{tabular}


Source: Data Analysis Result, 2019

In order to analyse multi-attribute attitude as a whole, there is a parameter of attitude value category toward attribute. The parameter of attitude value category is shown in Table 4 as follows:

Table 4 Attitude Value Category toward Attribute as a Whole

\begin{tabular}{lc}
\hline Attribute Attitude Value & Value \\
\hline Very Negative & $1,0 \leq$ Ao $\leq 5,8$ \\
Negative & $5,9 \leq$ Ao $\leq 10,6$ \\
Neutral & $10,7 \leq$ Ao $\leq 15,4$ \\
Positive & $15,5 \leq$ Ao $\leq 20,2$ \\
Very Positive & $20,3 \leq$ Ao $\leq 25,0$ \\
\hline
\end{tabular}

Source: Data Analysis Result, 2019

From the Fishbein Multi-Attribute Attitude Analysis on the consumers of bulk rice, it is known that the highest value is on the attributes of expiration clarity and ease of obtaining. Based on the attitude value category as a whole, both of these attributes have positive value (>15.4). On the other hand, other attributes are neutral (10.7-15.4). Positive attribute indicates the key factor that affects attitude and consumers' tendency in determining their choice.

Based on the analysis results, the bulk rice sellers should increase their positive attributes in order to increase the selling value. The expiration clarity of bulk rice can be directly identified by consumers through the sense of touch, smell, and sight. Rice that has been purchased can be seen and felt directly by consumers because it is not wrapped in packaging. Therefore, when the rice that is sold experienced a decrease in quality due to the storage periods, it will affect consumers' attitude. So does the case with the ease of obtaining. Rice is an absolute necessity for consumers, so they prefer to get the products that are easy to obtain.

\section{d. Belief Analysis of Packaged Rice}

Based on the analysis result, it is found that the attribute of expiration clarity has the best performance in consumers' perception. It can also be said that in forming the attitude toward the type of rice, consumers belief that the expiration clarity of packaged rice is the best compared to other attributes. The belief analysis result of packaged rice is shown in Table 5.

Table 5 Belief Analysis of Packaged Rice

\begin{tabular}{clc}
\hline No. & Attribute & $\mathbf{B i}$ \\
\hline 1 & Expiration clarity & 4,45 \\
2 & Ease of obtaining & 4,15 \\
3 & Taste & 4,10
\end{tabular}




\begin{tabular}{cll}
4 & Aroma & 4,05 \\
5 & Display & 4,01 \\
6 & Content & 3,96 \\
7 & Colors & 3,93 \\
8 & Texture & 3,92 \\
9 & Packaged size/portion & 3,85 \\
10 & Condition & 3,72 \\
11 & Price & 3,61 \\
\hline
\end{tabular}

Source: Data Analysis Result, 2019

\section{e. Fishbein Multi-Attribute Attitude Analysis of Packaged Rice}

Based on the Fishbein Multi-Attribute Attitude Analysis on packaged rice consumers, it is obtained the information that the expiration clarity, ease of obtaining, and content attributes have positive value. According to the attitude value category as a whole, these three attributes are positive (>15.4). Meanwhile, other attributes are neutral (10.7-15.4). Packaged rice consumers tend to belief that expiration clarity, ease of obtaining, and content are the important factors of rice.

Table 6 Fishbein Multi-Attribute Analysis of Packaged Rice

\begin{tabular}{clccc}
\hline No. & Attribute & $\mathbf{E i}$ & $\mathbf{B i}$ & ei.bi \\
\hline 1 & Expiration clarity & 4,26 & 4,45 & 18,96 \\
2 & Ease of obtaining & 4,08 & 4,15 & 16,95 \\
3 & Content & 3,89 & 3,96 & 15,43 \\
4 & Taste & 3,67 & 4,10 & 15,03 \\
5 & Aroma & 3,64 & 4,05 & 14,72 \\
6 & Texture & 3,71 & 3,92 & 14,55 \\
7 & Color & 3,66 & 3,93 & 14,37 \\
8 & Condition & 3,78 & 3,72 & 14,08 \\
9 & Display & 3,39 & 4,01 & 13,58 \\
10 & Price & 3,69 & 3,61 & 13,34 \\
11 & Package size/portion & 3,31 & 3,85 & 12,72 \\
\hline
\end{tabular}

Source: Data Analysis Result, 2019

\section{e. Importance Performance Analysis (IPA)}

Importance Performance Analysisin this study is the performance of a product compared to the consumers' expectation of the performance that it should have using Cartesius diagram. If Semantic Differential analysis uses line, IPA analysis only uses point (coordinate) to describe product performance. Furthermore, the attribute position in the diagram is interpreted more comprehensively to read the variable as stated by Bourgeois and Jesus (2004), quoting the work from Ténière-Buchot. Table 7 below is adapted from his work. 
HOLISTICA Vol 11, Issue 1, 2020, pp. 155-169

Table 7 Interpretation of Variable Position in Visualization Graphic

\begin{tabular}{|c|c|c|c|c|c|}
\hline \multirow{2}{*}{$\begin{array}{l}\text { Graphic } \\
\text { Position }\end{array}$} & \multicolumn{5}{|c|}{ Possibility of Lexical Domain and Related Meanings } \\
\hline & $\begin{array}{l}\text { Systemic } \\
\text { Driving }\end{array}$ & Communication & Power & Time & Interaction \\
\hline Upper left & $\begin{array}{l}\text { Variable } \\
\text { Leverage }\end{array}$ & Hypothesis & Strength & Past & Legitimacy \\
\hline Upper right & $\begin{array}{l}\text { Variable } \\
\text { Output }\end{array}$ & Stakes & Opportunity & Present & Action \\
\hline Lower right & $\begin{array}{l}\text { Variable } \\
\text { Marginal }\end{array}$ & Results & $\begin{array}{l}\text { Weakness } \\
\text { Incorrect }\end{array}$ & Future & Consideration \\
\hline Lower left & Variable & Discourse & problem & Instant & Communication \\
\hline
\end{tabular}

Source: e.1. IPA Analysis of Bulk Rice

The Importance Performance Analysis of bulk rice shows the attributes with the highest value for consumers, namely ease of obtaining, expiration clarity, and content. These three attributes belong to leverage variable, which is a variable that affects the attitude/action that is carried out at present. In this case, the leverage variable is the preference that affects consumers' attitude.

Figure 1 Importance Performance Analysis Matrix of Bulk Rice

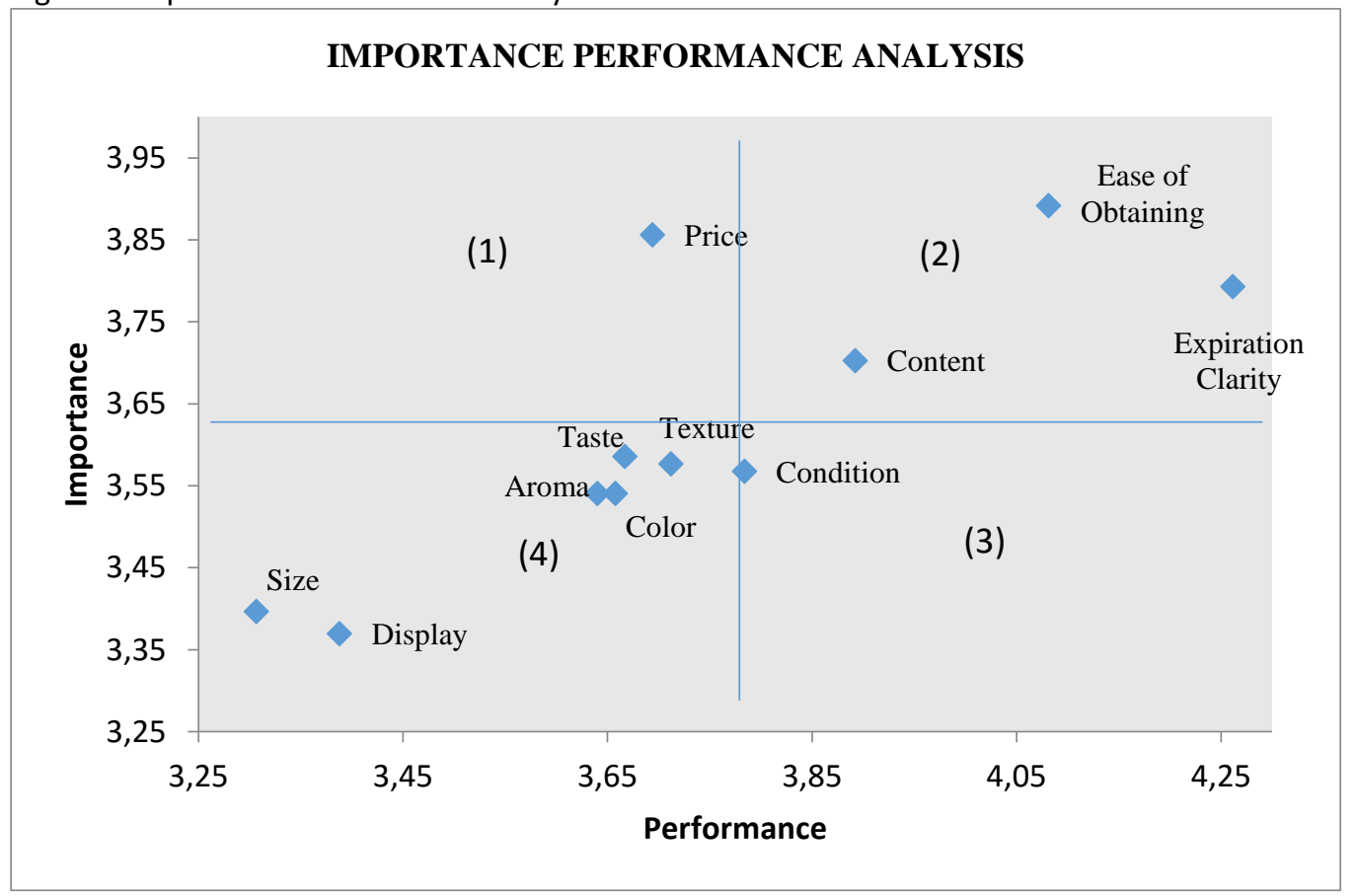

Source: e.2. IPA Analysis of Bulk Rice

Not much different with the IPA Analysis result of bulk rice, the Importance Performance Analysis result of packaged rice shows the highest value for consumers, namely expiration clarity and ease of access. Both of these attributes become the leverage variable in packaged rice as shown in Figure 2. 
HOLISTICA Vol 11, Issue 1, 2020, pp. 155-169

Figure 2 The Importance Performance Analysis Matrix of Packaged Rice

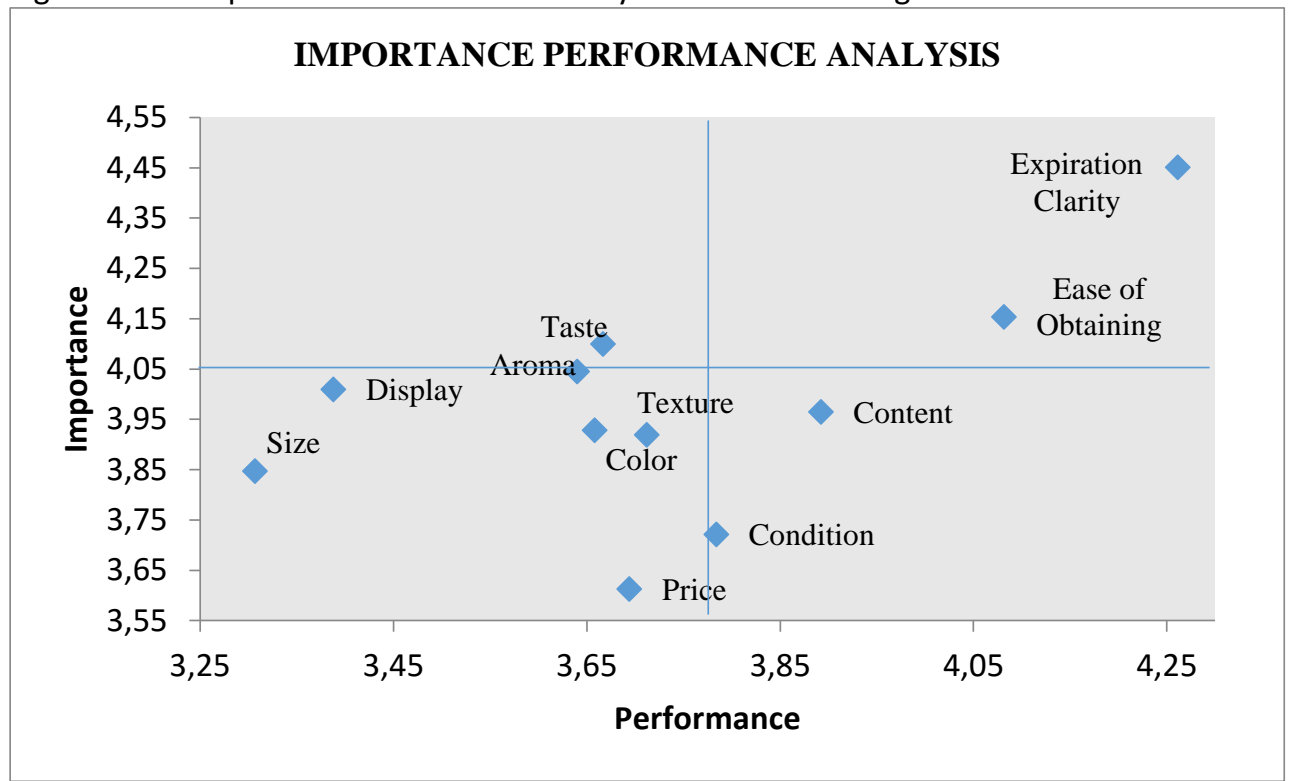

Source: e.2. IPA Analysis of Packaged Rice

\section{f. Belief Comparative Analysis Result}

The result of belief comparative analysis of bulk rice and packaged rice shows that bulk rice is only superior on price indicator, while packaged rice is superior on other indicators. The factor that cause bulk rice is superior in its price is because the price of bulk rice is cheaper than packaged rice, and consumers can also buy the rice per kilos, while packaged rice is usually sold in 5 kilos package. Therefore, the amount of money that will be spent less. This perception created the view that from the price indicator, bulk rice is more superior to packaged rice.

Table 8 Belief Comparative Analysis

\begin{tabular}{|c|c|c|c|}
\hline No. & Attribute & Bulk Rice & Packaged Rice \\
\hline 1 & Price & 3,86 & 3,61 \\
\hline 2 & Taste & 3,59 & 4,10 \\
\hline 3 & Package size/portion & 3,40 & 3,85 \\
\hline 4 & Display & 3,37 & 4,01 \\
\hline 5 & Condition & 3,57 & 3,72 \\
\hline 6 & Aroma & 3,54 & 4,05 \\
\hline 7 & Texture & 3,58 & 3,92 \\
\hline 8 & Content & 3,70 & 3,96 \\
\hline 9 & Color & 3,54 & 3,93 \\
\hline 10 & Ease of obtaining & 3,89 & 4,15 \\
\hline 11 & Expiration clarity & 3,79 & 4,45 \\
\hline
\end{tabular}


Source: Data Analysis Result, 2019

Consumer behavior is usually used to compare the attitude or perception of consumers toward certain products, in the form of figures. In Semantic Differential, product performance is reflected in the performance of a group of attribute which then compared to other type of products. Since it is presented in the form of figures, the conclusion that can be taken is only per attribute and cannot be concluded in general. The Semantic Differential in this study illustrates the performance comparison of bulk rice and packaged rice in the eyes of consumers.

Figure 3 Semantic Differential Matrix (Belief)

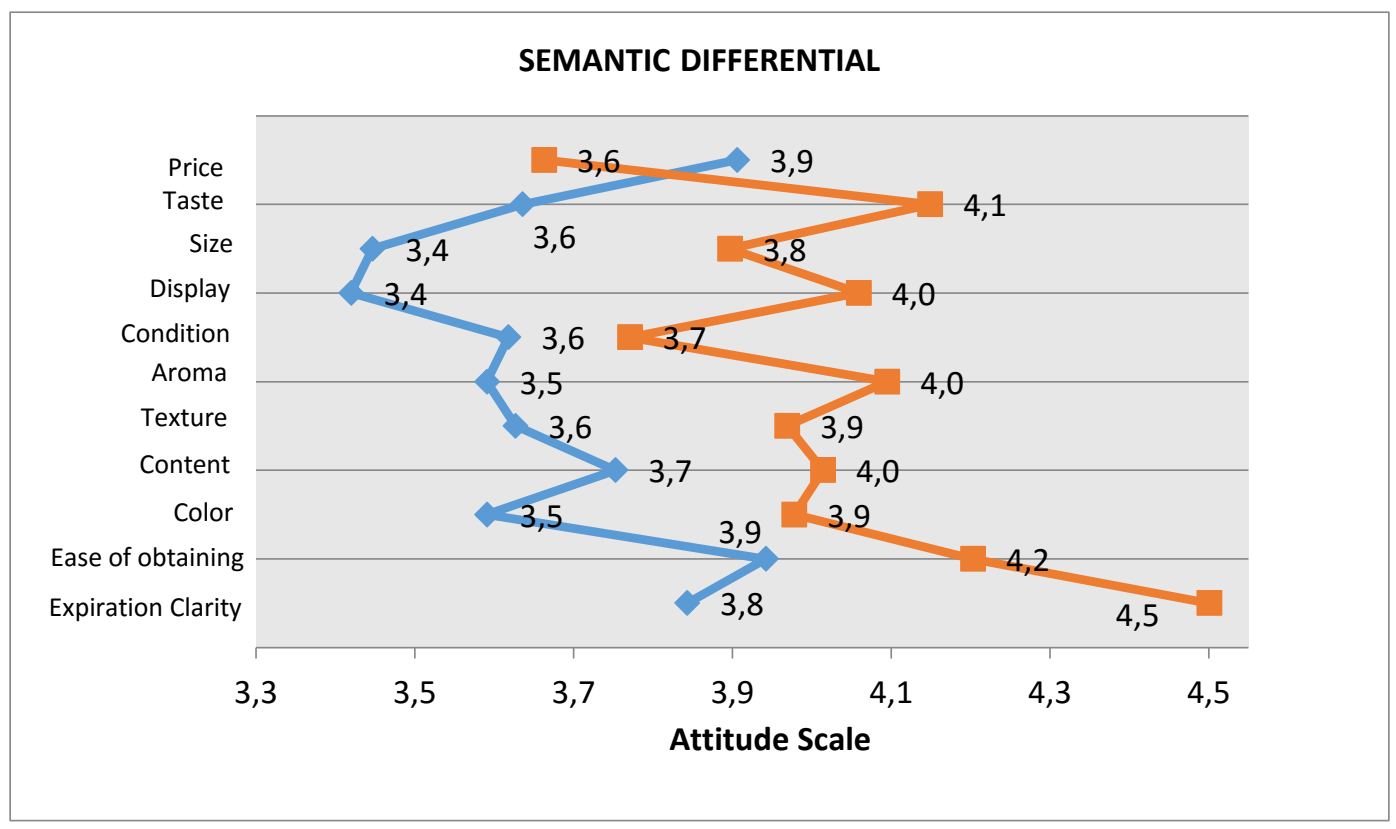

Source: Data Analysis Result, 2019

Based on the result of Semantic Differential comparative analysis in this study, it can be concluded that packaged rice is generally better based on the attributes that affect consumers' attitude and tendency compared to bulk rice (blue line colour). From several indicators/attributes that are tested, bulk rice only has the superiority on its price, while packaged rice (red line colour) has the superiority on other attributes. The result of this study can also be used as a basis for rice entrepreneurs/traders, both bulk rice and packaged rice entrepreneurs in order to improve the performance of their products. For example, packaged rice entrepreneurs can improve product performance through the price attributes. The strategies that can be used are price efficiency or differentiation of package size that is used.

The shift of rice as a staple food commodity to a consumer product has clearly been understood by the public. The community, especially urban consumers, is no longer buying rice because of their efforts to fulfil their basic needs, but also as a form of their 
HOLISTICA Vol 11, Issue 1, 2020, pp. 155-169

decisions and attitudes as consumers in choosing a product with complete attributes that suit their tastes as consumers. This is in line with the previous studies which stated that consumer attitudes toward packaged rice are good with the assessment of positive value attributes of competitive prices, attractive packaging and brands, and the availability of SNI (Indonesia National Standard) label (Syahrir, et al., 2015). Other attributes are still also considered with positive assessment, such as whole rice grains, the importance to choose certain varieties, and colour of rice.

Consumer preference will shape consumer attitude, which is also known as buying behavior. In food products, consumers' attitude towards a product are not only affected by the multi-attribute that attached to the product itself, but also the external factors of the product, such as the social culture of the local community and consumer psychology. The factors of product attribute which also determine consumers' attitude is price, place of sale, and form of product promotion (Anojan, 2015). In the position of rice as a product in the form of packaged rice, external factors in the form of community culture and consumer psychology will affect the decision of urban consumers in consuming certain types and brands of rice. Purchasing decision will relate to the type of product offered (Alessandro, 2014). Urban rice consumers prefer premium to medium quality with familiar brands in the community such as Tawon, Rajalele, and Putri Biru.

In each rice package, it is contained the messages of the origin of raw materials (the origin of rice) and nutrition aspects that is contained. The origin of rice and rice brands strengthen consumer psychology in determining the purchase attitude because it provides the idea of the quality of rice that will be consumed. The cultural factors of Indonesian society including urban consumers in consuming rice as main food are characterized by the frequency of rice purchases, and the quantity is then adjusted to the needs of household members, income, and location of purchase, so that it enables a variety of purchasing decision, namely daily, weekly, and monthly purchases with various type of rice, both bulk and packaged rice, and a combination of both. The culture of the people in consuming is also related to the physical form of rice which is identified by the colour, broken grain, and certain aroma in accordance with the culture of rice consumption that has been done for generations in their own family.

The nutritional aspect that is contained is one of the distinguishing attributes of bulk rice with packaged rice, since this information is only found in packaged rice through the information written on the package. Urban consumers generally like informative products in accordance with the psychology of urban consumers who are open to information, so that the complete information on the packaging becomes an attribute that will affect purchase decision. Whereas, on the bulk rice, information about the nutrition that is contained has been existed in each consumer's perception, which is the content of rice in general as a source of carbohydrates. Other attributes that considered important by rice consumers are the origin of rice and aroma (Anang, 2011). Based on the hedonic prices analysis, consumers are able to pay handsomely for the aroma and origin of rice. Thus, agro-industry actors should maintain the quality of this rice attributes to meet the tastes of consumers (Anang, 2011). 
HOLISTICA Vol 11, Issue 1, 2020, pp. 155-169

The assessment of consumers' preference is also related with market segmentation (Agustina, 2017). Rice as a basic need is consumed by the majority of Indonesia's people. Yet, rice as a product has its own market segmentation according to the type of product that is offered. The rice market which leads to monopolistic market is characterized by product differentiation in the form of the presence of various branded packaged rice that targets market segmentation.

Branded packaged rice was initially present at retail outlets or urban supermarkets to touch the upper middle class. However, in its development, branded packaged rice is present even in small kiosks to meet the demands of urban communities in the middle economy. In this case, the brand becomes a differentiator, where there are several rice brands such as Ramos and Rajalele Super that are sold in supermarkets. Some brands also provide 25 kilos packaging sold in supermarkets.

Consumer preference for the rice that will be purchased is also affected by several factors, namely marketing activities that are characterized by products variations in terms of packaging, brand and size, promotion, product quality, and customer testimonials (Suwanapom, 2014). These factors illustrate consumer tastes and determine purchasing attitudes. In addition, the education level of urban communities also determines the choice of rice in a household because these factors tend to describe the income and openness of consumers toward information (Mottaleb, 2016). In agricultural product, the decision to purchase and choose of the consumers is also determined by the attributes of product certification, availability of stock, packaging, and prices (Sutarni, 2017). Product certification and availability of stock have not been an attribute of assessment in the analysis of consumer attitude toward rice attributes in this study.

\section{Conclusion}

The results of the study can be concluded that:

- The assessment of consumers' attitude toward bulk rice and packaged rice shows that there are attributes that are classified as positive value $(>15.4)$ for consumers, which are the attributes of expiration clarity (in both bulk and packaged rice), ease of obtaining (attribute in bulk rice), and content (attribute in packaged rice). Positive attributes indicate the key factors that affect consumers' attitude and tendency in determining their choices. This result is also strengthened by the IPA (Important Performance Analysis) result which states that these attributes are included in the leverage variable, a variable that affects current attitudes/actions. In this case, the leverage variable is the preference that affects consumers' attitude.

- The result of Semantic Differential comparative analysis shows that branded packaged rice is generally better based on the attributes that affect consumers' attitude and tendency compared to bulk rice. 


\section{Theory and Managerial Implication}

Consumer tastes are known as factors that affect product demand, as well as in rice that has developed into heterogeneous product. In order to improve the welfare of producers, rice agro industry at the level of local farmers who process farmers' bulk rice into branded packaged rice with competitive quality targeting the downstream rice center is worth seeking out. This cuts the length of the rice marketing chain while also increases the added value of local farmers' rice, so that it has an impact on increasing income. Branded packaged rice produced by local agro-industries is expected to meet the rice multiattribute such as expiration clarity, ease of obtaining, content, size choice, and competitive prices.

\section{Acknowledgement}

The author would like to thank to LPPM UPN Veteran Jawa Timur, Agriculture Faculty UPN Veteran Jawa Timur and Agribussiness Departement of UPN Veteran Jawa Timur for all the support of this research.

\section{References}

Abidin,Z. Prastika, R., \& Septya, F. (2018). Reviewing Government Policy on Rice Price: Study Through Rice Price In East Java Market. Proceedings of the International Conference on Science and Technology (ICST 2018).

Agbarevo, M. N. B. \& Obine, C. P. O, Agricultural Marketing Extension;Element of Rural Sociology and Agricultural;Extension, Teo Publishers, 190-198.

Agustina, I., Sumarwan, U., \& Kirbrandoko, K. (2017). Consumer Preferences and Segmentation Analysis of Bogor Culinary Tourism. Journal of Consumer Science, Vol 2 No 1: 13-24.

Ajzen, I., \& Fishbein, M. (1975). Belief, Attitude, Intention and Behavior: An Introduction to Theory and Research. Reading, MA: Addison-Wesley.

Alessandro, S. \& Lusia, S. (2014). The Relationship Between Product and Consumer Preference for Agrifood Product: Red Orange of Silicy Case. IERI Procedia. Vol 8: 25-29

Anang, B.T., Adjetey, S.N., \& Abiriwe, S.A. (2011). Consumer Preferences of Rice Quality Characteristic and the Effect of Pice in Tamale Metropolis, Northern Region, Ghana. International Journal of Agriscience. Vol 1(2): 67-74.

Anojan, V., \& Subaskaran, T. (2015). Consumer Preference and Consumer Buying Behaviour Soft Drinks : A case Study in Northern Province of Srilanka. Global Journal of Management and Bussiness Research EMarketing. Vol 12 No 2: 10-33

Basorun (2012). Analisis Empiris Faktor-Faktor Dasar Pemasaran Beras Di wilayah IGBEMO. Nigeria. Vol. 3. No 2

[BPS] Badan Pusat Statistik Kota Surabaya. (2018). Statistik Daerah kota Surabaya, Surabaya

Bourgeois, R., \& Jesus, F. (2004). Participatory prospective analysis: exploring and anticipating challenges with stakeholders (No. 1437-2016-118895), UNESCAP-CAPSA. Capsa No.46.

Dirisu, J.I., Iyiola, J.O., \& Ibidunni, O.S. (2013). Product Diffrentiation: A Tool of Competitive 
HOLISTICA Vol 11, Issue 1, 2020, pp. 155-169

Advantages and Optimal Organizational Performance (A Study of Nigeria PLC). European Scientific Journal. Vol 19(34): 258-281

Engel, J.F., Blackwell, R.D., \& Miniard, P.W. (1994). Perilaku Konsumen. Terjemahan. Jakarta: Binarupa Aksara.

Eze, O. E. (2010). Kendala Pemasar Perempuan, Persepsi Tentang Pemilihan Pemasaran Produksi Pertanian Di Wilayah Enugu Selatan: Tantangan Pelatihan Extension Bagi Perempuan Kelompok Inenugu, Nigeria, Agro-Science Journal of Tropical Agriculture, Food. Vol. 9: 215-222.

Giri. S., \& Shankar, S. (2013). Perspektif Pegolahan BerasPerusahaan Di India. U.M.U.S.C., Vol 4. No 1.

Kumboro, ERH. (2016). Pengaruh Karakteristik dan Preferensi Konsumen Terhadap Keputusan Membeli Beras di Kota Medan. Tesis Pascasarjana Universitas Sumatera Utara.

Widodo, A., Aji, M., \& Murti, J. (2010). Perilaku Konsumen pada Pembelian Beras Bermerk di Kabupaten Jember dan Faktor yang Mempengaruhinya. Jurnal Sosial Ekonomi Pertanian, 4(3), 22680.

Ramdhani, A. A., Alamanda, D.T., \& Sudrajat, H. (2012). Analysis of Consumer Attitude Using Fishbein Multiattributes Approach, International Journal of Basic and Applied Sciences, Vol 01(01): 33-39

Rohman, A., Helmiyati, S., Hapsari, M., \& Setyaningrum, D.L. (2014). Rice in Health and Nutrition, International Food Research Journal, Vol 21 (1): 13-24

Sangadji, E.M., \& Sopiah, (2013). Consumer Behavior: Perilaku Konsumen dan Strategi Pemasaran Jilid 2. Jakarta: Erlangga.

Schifman LG., \& Kanuk, L. L. (2004). Consumer Behaviour. 8th edition. New Jersey: Pearson Education.

Septya, F., Widayanti, S., Sudiyarto, S., \& Amir, I. T. (2018). Struktur Dan Perilaku Pasar Beras Surabaya. Berkala IImiah AGRIDEVINA, 7(1), 27-39.

Sumarwan, U. (2000). Analisa Sikap Multiatribut Fishbein terhadap Produk Biskuit Sandwich Coklat, Media Gizi dan Keluarga. Vol. XXIV(2): 79 - 85

Sutarni, T.T.B., \& Unteawati, B. (2017). Preferensi Konsumen Terhadap atribut Produk Sayuran Organik di Kota Bandar Lampung, Jurnal Penelitian Pertanian Terpadu, Vol 17(3): 203-211

Suwanapom, P. \& Linneman, A. (2014). Consumer Preferences and Buying Criteria in Rice: A Study to Identify Market Strategy for Thailand asmine Rice Export, Journal of Food Product Marketing, Vol 14 No 4: 33-53

Syahrir, T.S.A.A., \& Bahari, (2015). Preferensi Beras Kemasan Berlabel, Jurnal Agroekonomika UTM, Vol 4 No 1: 10-21.

Tambunan, T. (2008). Tataniaga dan Pengendalian Harga Beras Di Indonesia. Kadin

Ukav, (2017). Market Structure and Concentration Measuring Techniques, Asian Journal of Agriculture Extension, Ecoomics, Sociology, Vol 19(4): 13-24 